\author{
Military Technical College \\ Kobry Elkobbah, Cairo, \\ Egypt.
}

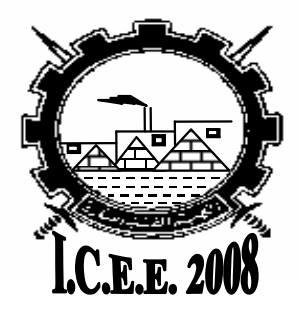

$4^{\text {th }}$ International Conference On

Chemical \& Environmental

Engineering

27-29 May 2008

\title{
A LOW COST CONVERSION METHOD OF AGRO-RESIDUE TO COAGULANT AID
}

\author{
S. A. Abo-El-Enein*, M. A. Eissa** ,A. A. Diafullah*** \\ M. A. Rizk ${ }^{* * *}$, and F. M. Mohamed ${ }^{* *}$
}

\begin{abstract}
Rice is one of the major crops grown throughout the world, it covers $1 \%$ of the earth's surface and is a primary source of food for billions of people Globally, approximately 600 million tons of rice paddy is produced each year. On average $20 \%$ of the rice paddy is husk, giving an annual total production of 120 million tons. In Egypt, the annual rice production is about $5,700,000$ tons, equivalent to 200,000 tons of rice husk ash .After the separation of the rice from the paddy, one - third of the mass remains as a waste material ..Many workers have tried to use this agricultural waste to produce useful materials such as silica, zeolite, silica gel silicon carbide, activated carbon and sodium silicate notation coagulant aid. Rice husk ash is one of the most silica rich raw materials containing about $90-98 \%$ silica (this quantity depends on the soil type, plant variety and climatic conditions, geological factor, type of ground, near of harvest, sample preparation and analysis method..etc.The chemical process discussed below not only provides a solution for waste disposal but also recovers a valuable silica product, together with certain useful associate recoveries The activated silica or sodium silicate is one of the four basic types of coagulants aids beside $\mathrm{pH}$ adjusters, clay and polymers which increase a stability of coagulant and can unite with the positively charged aluminum or with iron flocs, resulting in a larger, denser lamellar floc that settles faster and enhances enmeshment.

The objectives of this study were to :produce rice husk ash (RHA) from rice husk, produce sodium silicate, and characterizations of new materials obtained by FTIR, XRD, and SEM. Under the study condition it was found that selected sample (optimum condition), of RHA which is designated as $\mathrm{RHA}_{5}$ obtained by calcination of untreated $\mathrm{RH}$ at $650^{\circ} \mathrm{C}$ in semi closed system. FTIR shows signals at 1098 and $800 \mathrm{~cm}^{-1}$ for Si-O and O-Si-O respectively; XRD shows a sharp signal (amorphous silica ) at $2 \theta=22^{\circ}$ and SEM examination indicate that rectangular particles should be distinguished. whereas $\mathrm{RHA}_{5}$ used in manufacturing of sodium silicate which is designated as $\mathrm{Ssi}_{5}$ and identified by XRD with its characteristic peak at $2 \theta$ about $28^{\circ}$, FTIR shows signals at $(1443,994)$ for $\mathrm{Si}-\mathrm{O}-\mathrm{Si}$, NFTIR shows signal at 7326 for overtone $\mathrm{OH}$ stretching $\mathrm{Si}-\mathrm{OH}$.
\end{abstract}

KEY WORDS : Rice, Rice husk Ash, Active silica and Sodium silicate

\footnotetext{
* Faculty of science, Ain shams university, Egypt

** Kaha Company for Chemical Industries, National Authority for Military Production. Egypt

*** Atomic Energy Authority, Egypt.
} 


\section{INTRODUCTION}

Rice is one of the major crops grown throughout the world .After the separation of the rice from the paddy, one - third of the mass remains as a waste material . Many workers have tried to use this agricultural waste to produce useful materials such as silica, silicon carbide, activated carbon, sodium silicate, silica gel, and zeolite [1].

Rice covers $1 \%$ of the earth's surface and is a primary source of food for billions of people. Globally, approximately 600 million tonnes of rice paddy is produced each year. On average $20 \%$ of the rice paddy is husk, giving an annual total production of 120 million tonnes. In Egypt, the annual rice production is about 5,700,000 tons, equivalent to 200,000 tons of rice husk ash, in the majority of rice producing countries much of the husk produced from the processing of rice is either burnt or dumped as waste [2].

Rice husk is a by-product from rice mill that was used as an energy source in many industries such as biomass power plant and rice mill. Burning rice husk generates rice husk ash (RHA) which is rich in silica and can be an economically valuable raw material for production of natural silica [3].

There are several methods for the extraction of silica from biomass. Many authors, [47] have suggested that acid preliminary treatment before thermal treatment is a reasonable method for natural silica extraction. The high purity of silica and low mineral impurity are retrieved by boiling in hydrochloric solution for $1 \mathrm{~h}$ followed by burning in the atmosphere at $650-700{ }^{\circ} \mathrm{C}$ for $4 \mathrm{~h}[5]$. By means of this method, the extracted silica is found in a form of amorphous structure which is the most reactive form for silylation reaction[5].

Rice husk is unusually high in ash compared to other biomass fuels - close to $20 \%$. The ash is 92 to $95 \%$ silica $\left(\mathrm{SiO}_{2}\right)$, highly porous and lightweight, with a very high external surface area. Its absorbent and insulating properties are useful to many industrial applications, and the ash has been the subject of many research studies [2].

Rice husk ash has many applications due to it's various properties. It is an excellent insulator, so has applications in industrial processes such as steel foundries, and in the manufacture of insulation for houses and refractory bricks. It is an active pozzolan and has several applications in the cement and concrete industry. It is also highly absorbent, and is used to absorb oil on hard surfaces and potentially to filter arsenic from water [2].

RHA is a general term describing all types of ash produced from burning rice husks. In practice, the type of ash varies considerably according to the burning technique. Two forms predominate in combustion and gasification. The silica in the ash undergoes structural transformations depending on the temperature regime it undergoes during combustion. At $550^{\circ} \mathrm{C}-800^{\circ} \mathrm{C}$ amorphous silica is formed and at greater temperatures, crystalline silica is formed [2].

Sodium silicate, the precursor for silica production, is currently manufactured by smelting quartz sand with sodium carbonate at $1300^{\circ} \mathrm{C}$ [8-9] This conventional technology requires high energy costs, produce considerable air pollution, impure of the product and need to maintenance of oven due to attack of base that could be avoided by processing rice hull silica, instead of sand, by ambient temperature methods. Rice hull ash is produced commercially by hull combustion and contains over $60 \%$ silica and can be an economically viable raw material for the production of silicates, silica gel,zeolite and silica [10-11]. 
The presence of silica in rice husk $(\mathrm{RH})$ has been known since $1938^{\left[{ }^{[12]}\right.}$ Rice husks produce a high ash content, varying from 13 to $29 \mathrm{wt} . \%$ depending on the variety, climate, and geographic location. The ash is largely composed of silica (87-97\%) with small amounts of inorganic salts ${ }^{[13]}$ Due to its high silica content RH has become a source for preparation of a number of silicon compounds such as silicon carbide[1415] ,silicon nitride [16] ,sialon, zeolite[17], silica ash obtained by calcining RH is also used in the cement industry. $\mathrm{RH}$ silica has fine particle size and high reactivity and has been used in the production of activated silica, sodium silicate, potassium silicate and solar grade silicon [18]. Though the ash of $\mathrm{RH}$ is rich in silica, the raw $\mathrm{RH}$ contains mainly organic matter ( $\approx 85 \%)$ composed of cellulose, lignin, d-xylose, small quantities of methyl glucuronic acid and d-galactose, and small quantities of proteins and vitamins, inorganic compounds [19]. The elemental analysis of the organic matter as calculated by Sharma et al. is 51 wt.\% carbon, 7 wt.\% hydrogen and 42 wt.\% oxygen[19].

The four basic types of coagulants aids are $\mathrm{pH}$ adjusters, activated silica, clay and polymers. Activated silica has been used as a flocculants since the 1930's to strengthen flocs and reduce the potential of deterioration [20] When activated silica is added to water, it produces a stable solution that has a negative surface charge. The activated silica can unite with the positively charged aluminum or with iron flocs, resulting in a larger, denser floc that settles faster and enhances enmeshment.

The addition of activated silica is especially useful for treating highly colored, lowturbidity waters cause it adds weight to the floc., It is usually produced on-site by reacting sodium silicate with an acid to form a gel [21].When using activated silica, the resultant floc is larger, denser, more chemically stable, and settles faster than iron and aluminum flocs[20] .

Silicate compounds were first used as a coagulation aid because of their ability to adsorb onto particles and decrease surface charge. These properties were soon applied to sequestration (dispersion) of iron particles in distribution systems[22-26]. Addition of silicate-based inhibitors has also been found to reduce iron corrosion rate[27]. Finally, silicates are reported to decrease the oxidation of $\mathrm{Fe}^{+2}$ because ferrous iron diffusion through the silicate film is slower than through iron oxide scale [28].

\section{The objectives of this study were to :}

Produce rice husk ash (RHA) from rice husk, produce sodium silicate, and characterizations of new materials obtained by FTIR, XRD, and SEM.

\section{Materials and Experimental procedure}

\subsection{Materials}

All reagents used are of commercial grade except sodium hydroxide is an analytical grade product. Deionized water was used to make all solutions

\subsection{Experimental procedure}

The experimental part is divided into two main sections:

The first section concerned with the preparation and characterization of five samples of rice husk ash (RHA) $\mathrm{RHA}_{1}$ and $\mathrm{RHA}_{2}$ were prepared by burning of $\mathrm{RH}$ for 
2 hrs in muffle furnace at $850^{\circ} \mathrm{C}, 650^{\circ} \mathrm{C}$, respectively, after treatment with hydrochloric acid $10 \%$ for $1 \mathrm{hr}$ in reflux at $100^{\circ} \mathrm{C}$. $\mathrm{RHA}_{3}$ and $\mathrm{RHA}_{4}$ were prepared by burning of $\mathrm{RH}$ for $2 \mathrm{hrs}$ of in muffle furnace at $850^{\circ} \mathrm{C}, 650^{\circ} \mathrm{C}$, respectively, after washing with distilled water . $\left(\mathrm{RHA}_{5}\right)$ was prepared by burning of $\mathrm{RH}$ for $2 \mathrm{hrs}$ in muffle furnace at $650^{\circ} \mathrm{C}$.

The second section concerned with the preparation of sodium silicate. RHA samples were reacted with sodium hydroxide with a molar ratio $\mathrm{SiO}_{2} / \mathrm{NaOH}$ of $1: 2$ in reflux at $100^{\circ} \mathrm{C}$ for $1 \mathrm{hr}$ or until no silica residue to select optimal condition. The solution of sodium silicate are designated as $\mathrm{SSi}_{2}, \mathrm{SSi}_{4}$ and $\mathrm{SSsi}_{5}$ according to the type of RHA of $\mathrm{RHA}_{2}, \mathrm{RHA}_{4}$ ' and $\mathrm{RHA}_{5}$, respectively .

The RHA and sodium silicate were characterized by $X$ Ray Diffraction (XRD) CuKapw 3050/60-2006, Fourier Transform Infra Red (FTIR) (Jasco FT/ IR 460 plus, and Scanning Electron Microscope (SEM) JOEL JEM-100S.

\section{3 .Results and discussion}

\subsection{The first section:}

The data listed in table (1) describe the chemical properties of five samples of rice husk ash and comparison with a previous literature[31]. It can be evidenced that the ash produced from the rice husk burning contains a great amount of silica and small amounts of other elements considered as impurities. The most common trace elements in RHA are sodium, potassium, calcium, magnesium, iron, titanium , manganese and chloride ${ }_{299}$. Differences in composition may occur due to geographical factors, type of ground, year of harvest, sample preparation and analysis method , In $\mathrm{RHA}_{1}$ the sample was burnt at $850{ }^{\circ} \mathrm{C}$ after treatment with acid ( no metal oxide residue and the content of silica reach to $99.2 \%$ ). In $\mathrm{RHA}_{2}$ the sample was burnt at $650{ }^{\circ} \mathrm{C}$ after treatment with acid ( no metal oxides residue and the content of silica reach to $98.5 \%$ ) and residue may be unconvertible metal oxide. In $\mathrm{RHA}_{3}$ the sample burnt was at $850{ }^{\circ} \mathrm{C}$ with no treatment with acid ( only washed with distilled water) in which the content of silica reach to $90 \%$ and metal oxide appear as show in table(1). In $\mathrm{RHA}_{4}$ where the sample burnt at $650{ }^{\circ} \mathrm{C}$ with no treatment with acid but only washed with distilled water (the content of silica reach to $89 \%$ and metal oxides less than $7 \%$ due to partial dissolution of these oxides in distilled water). In $\mathrm{RHA}_{5}$ the sample was burnt at $650{ }^{\circ} \mathrm{C}$ with no acid treatment and no water washing, (the content of silica reach to $87.5 \%$ and metal oxide reach to $8 \%$ ) .

Figs. (1-2) describe the X-ray diffractogram of the $\mathrm{RHA}_{1}$ and $\mathrm{RHA}_{2}$ which indicate that the amorphous silica peak appeared around $2 \theta$ equal to $22^{\circ}$ as a result of calcinations of rice husk at 850 and $650^{\circ} \mathrm{C}$, respectively, after treatment with $\mathrm{HCl}$ $10 \%$ may be due to formation of silicon tetrachloride by chlorination technique[3,5,30]. Figs. (3\&4) describe the X-ray diffractogram of the $\mathrm{RHA}_{3}$ and $\mathrm{RHA}_{4}$ which indicates the crystalline silica sharp peak appeared around $2 \theta$ equal to $22^{\circ}$ resulted from calcination of rice husk at 850 and $650^{\circ} \mathrm{C}$, respectively, after washing with distilled water Fig. (5) describes the X-ray diffractogram of the $\mathrm{RHA}_{5}$ indicates the amorphous silica peak appeared around $2 \theta$ equal to $22^{\circ}$ resulted from calcination of rice husk at $650^{\circ} \mathrm{C}$, with no washing, the $\mathrm{RHA}_{2}$ and $\mathrm{RHA}_{5}$ are active towards the synthesis of sodium silicate ${ }^{[31,32]}$. Another observation is the effect of precalcination temperature on increasing the crystallinity of untreated rice husks with $\mathrm{HCl}$. It was 
verified that no acid treatment process also affects the increase of the degree of crystallinity of the precalcined rice husks. [30]

Figs.6 (a-e) describe the FTIR of the five RHA samples, FTIR spectrum of RHA ( $_{1}$ fig.6a ) displayed characteristic bands for Si-O , and Si-O-Si , at 1101 and $803 \mathrm{~cm}^{-}$ ${ }^{1}$, respectively, ${ }^{[33-34]}$. FTIR spectrum of $\mathrm{RHA}_{2}$ ( fig. 6b) displayed characteristic bands for Si-O and Si-O-Si at 1092 and $791 \mathrm{~cm}^{-1}$,respectively,[33-34] .FTIR spectrum of $\mathrm{RHA}_{3}$ ( fig. 6c) displayed characteristic bands for Si-O, and Si-O-Si at 1100 and 803 $\mathrm{cm}^{-1}$, respectively,[33-34]. FTIR spectrum of $\mathrm{RHA}_{4}$ ( fig.6d) displayed characteristic bands for Si-O and Si-O-Si at 1100 and $802 \mathrm{~cm}^{-1}$, respectively,[33-34]. FTIR spectrum of $\mathrm{RHA}_{5}$ ( fig.6e) displayed characteristic bands for $\mathrm{Si}-\mathrm{O}$ and (Si-O-Si) at $1098,800 \mathrm{~cm}^{-1}$,respectively, [33-34].

The morphology of silica extracted from RHA of $\mathrm{RHA}_{1}$ and $\mathrm{RHA}_{2}$ are shown in Figs.7 and 8 , respectively. Different shapes of silica particles; globular and rectangular shapes, were found in the extract. Even though the grinding of the extract was carried out before SEM measurement, the silica depositing along the skeleton of rice husk (rectangular structure) was remaining in the extract. While the fine silica particles were appeared in the globular shapes, the black parts in $\mathrm{RHA}_{1}$ is less than that of $\mathrm{RHA}_{2}$ due to the brightness which increases with the increase in temperature of calcination $[35,36]$.

\subsection{The Second Section}

The data listed in table (2) describe the chemical properties of three samples of sodium silicate; The solution of sodium silicate are designated as $\mathrm{SSi}_{2}, \mathrm{SSi}_{4}$ and $\mathrm{SSsi}_{5}$ according to the type of RHA of $\mathrm{RHA}_{2}, \mathrm{RHA}_{4}$ and $\mathrm{RHA}_{5}$, respectively; the practical ratio between sodium oxide and silica is about $1: 2.2$ and it is confirmed with the recommended procedure.

The morphology of sodium silicate prepared from rice husk ash without washing is shown in Fig. 9, with different shapes of silica particles; globular and rectangular shapes were found.The FTIR spectrum shown in fig.10 displayed the characteristic bands of sodium silicate for, silanol $\mathrm{OH}$ groups and adsorbed water, Si-O-Si and AlO-Si at broad band (2923-3390) $\mathrm{cm}^{-1}$, (994-1443) $\mathrm{cm}^{-1}$ and (464-877) $\mathrm{cm}^{-}$ ${ }^{1}$ respectively [33-34,37]. NFTIR spectrum shown in fig.11 displayed characteristic bands of sodium silicate for, overtone $\mathrm{OH}$ - stretch $\mathrm{Si}-\mathrm{OH}$, overtone $\mathrm{OH}$-stretching, (OH-stretching(2) crystal water, $\mathrm{H}_{2} \mathrm{O}$ combination), and $\mathrm{H}_{2} \mathrm{O}$ bending at $7327 \mathrm{~cm}^{-1}$ (6971- 6611) $\mathrm{cm}^{-1},(5338-5204) \mathrm{cm}^{-1}$ and $4451 \mathrm{~cm}^{-1}$, respectively,[35] . Fig .12 shows the $\mathrm{x}$-ray diffraction pattern of sodium silicate powder obtained by grinding after drying at $105^{\circ} \mathrm{C}$ for $2 \mathrm{hrs}$ which indicates a sharp peak appeared around $2 \theta$ equal to $28^{\circ}$ ( $\mathrm{d}$ spacing $3.24 \mathrm{~A}^{\circ}$ )

[ 37], And abroad band around $2 \theta$ equal to $12.5^{\circ}\left(\mathrm{d}\right.$ spacing $9.43 \mathrm{~A}^{\circ}$ ) due to low content of adsorbed water in sodium silicate powder [37].

\subsection{Effect of neutralization time}

The time -silica consumption was presented in Fig ( 13 ) and comparison depending on the type of silica and treatment procedure the three lowest cost samples namely $\left(\mathrm{RHA}_{2}, \mathrm{RHA}_{4}\right.$ and $\left.\mathrm{RHA}_{5}\right)$ were selected. The time of neutralization is longer in $\left.\mathrm{RHA}_{4}\right)$ where as the type of silica is crystalline silica according the XRD analysis ) than that in $\mathrm{RHA}_{2}$ and $\mathrm{RHA}_{5}$ where the type of silica is amorphous silica according the XRD analysis may be due to metal oxide in $\mathrm{RHA}_{5}$ enhances neutralization while the 
pretreatment of $\mathrm{RHA}_{2}$ with acid increases activity of silica (amorphous silica) $\mathrm{RHA}_{4}$. More than $50 \%$ of silica is consumed within half hour in $\mathrm{RHA}_{5}$; but less than $50 \%$ of silica in $\mathrm{RHA}_{4}$ need more than half hour to consuming. At one hour of neutralization a small quantity of silica residue $5 \%$ is found in $\mathrm{RHA}_{5}$ but remaining residues is about $20 \%$ still in $\mathrm{RHA}_{4}$. After storage no exchange in silicate prepared in $\mathrm{RHA}_{2} \mathrm{RHA}_{5}$ but some silica return to suspend in solution of $\mathrm{RHA}_{4}$.

\section{CONCLUSIONS}

Within limits of the present study the following conclusions can be established:

1) Rice husk ash was a low cost alternative source of active silica and highly pure silica ( $99 \%$.wt)

2) The activated silica or sodium silicate is one of the four basic types of coagulants aids beside $\mathrm{pH}$ adjusters, clay and polymers which increase a stability of coagulant and can unite with the positively charged aluminum or with iron flocs, resulting in a larger, denser lamellar floc that settles faster and enhances enmeshment .

3) It is possible to obtain a high silica content by applying simple technique and it is possible to transform agroresidue or industrial residue to useful materials , avoiding damage to the environment.

4) The most suitable procedures for synthesis of sodium silicate (co-agulant aid ) were to be :

- the reaction of sodium hydroxide with amorphous activated silica derived from RHA without treatment at $650{ }^{\circ} \mathrm{C}$.

- the reaction of sodium hydroxide with crystalline activated silica previously washed with distilled water at $650{ }^{\circ} \mathrm{C}$

- the reaction of sodium hydroxide with amorphous activated silica previously treated with $\mathrm{HCl} 10 \%$ at $650^{\circ} \mathrm{C}$. 
Table (1): Chemical analysis of the five RHA samples prepared as compared with a reference

\begin{tabular}{|c|c|c|c|c|c|c|}
\hline $\begin{array}{c}\text { Parameter } \\
(\%)\end{array}$ & $\mathrm{RHA}_{1}$ & $\mathrm{RHA}_{2}$ & $\mathrm{RHA}_{3}$ & $\mathrm{RHA}_{4}$ & $\mathrm{RHA}_{5}$ & $\begin{array}{c}\text { Reference } \\
{[32]}\end{array}$ \\
\hline $\mathrm{SiO}_{2}$ & 99.2 & 98.5 & 90 & 89 & 87.5 & $62.5-97.6$ \\
\hline $\mathrm{Fe}_{2} \mathrm{O}_{3}$ & - & - & 2.0 & 2.0 & 2.0 & $0.01-2.78$ \\
\hline $\mathrm{MnO}$ & - & - & 0.043 & 0.043 & 0.043 & $0.01-1.96$ \\
\hline $\mathrm{AL}_{2} \mathrm{O}_{3}$ & - & - & 1.0 & 1.0 & 1.0 & $0.01-1.01$ \\
\hline $\mathrm{MgO}$ & - & - & 0.7 & 0.7 & 0.7 & $0.01-1.96$ \\
\hline $\mathrm{CaO}$ & - & - & 0.65 & 0.65 & 0.65 & $0.1-1.31$ \\
\hline $\mathrm{Na}_{2} \mathrm{O}$ & - & - & 1.0 & 1.0 & 1.45 & $0.01-1.58$ \\
\hline $\mathrm{K}_{2} \mathrm{O}$ & - & - & 1.55 & 1.55 & 2.1 & $0.1-2.54$ \\
\hline $\mathrm{P}_{2} \mathrm{O}_{5}$ & - & - & 0.057 & 0.057 & 0.057 & $0.01-2.69$ \\
\hline Residue & $\approx 0.8$ & $\approx 1.5$ & $\approx 3.0$ & $\approx 4.0$ & $\approx 4.5$ & - \\
\hline
\end{tabular}

Table (2) : Chemical analysis of the three dry sodium silicate samples

\begin{tabular}{|c|c|c|c|}
\hline Parameter (\%) & $\begin{array}{c}\text { Sodium silicate } \\
\left(\mathrm{SSi}_{2}\right)\end{array}$ & $\begin{array}{c}\text { Sodium silicate } \\
\left(\mathrm{SSi}_{4}\right)\end{array}$ & $\begin{array}{c}\text { Sodium silicate } \\
\left(\mathrm{SSi}_{5}\right)\end{array}$ \\
\hline $\mathrm{SiO}_{2}$ & 69.5 & 66 & 64.4 \\
\hline $\mathrm{Na}_{2} \mathrm{O}$ & 29.5 & 29 & 29 \\
\hline $\mathrm{MnO}$ & - & 0.027 & 0.028 \\
\hline $\mathrm{AL}_{2} \mathrm{O}_{3}$ & - & 0.64 & 0.65 \\
\hline $\mathrm{MgO}$ & - & 0.3 & 0.45 \\
\hline $\mathrm{CaO}$ & - & 0.35 & 0.42 \\
\hline $\mathrm{Fe}_{2} \mathrm{O}_{3}$ & - & 1.15 & 1.3 \\
\hline $\mathrm{Na}_{2} \mathrm{O}$ & - & 0.89 & 0.94 \\
\hline $\mathrm{K}_{2} \mathrm{O}$ & - & 1.2 & 1.35 \\
\hline $\mathrm{P}_{2} \mathrm{O}_{5}$ & - & 0.034 & 0.036 \\
\hline $\mathrm{Residue}$ & $\approx 1.0$ & $\approx 0.4$ & $\approx 1.0$ \\
\hline
\end{tabular}




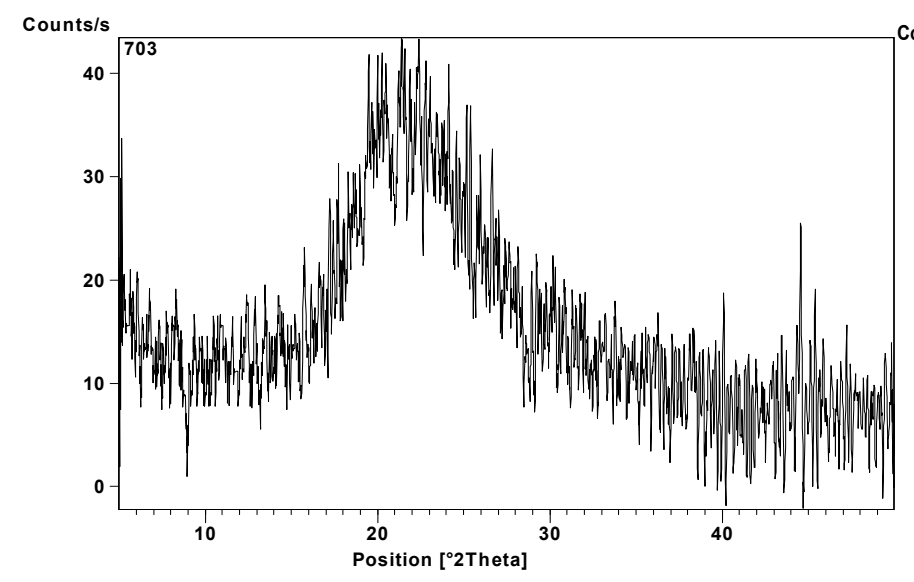

Fig.( 1) : XRD pattern of $\mathrm{RHA}_{1}$

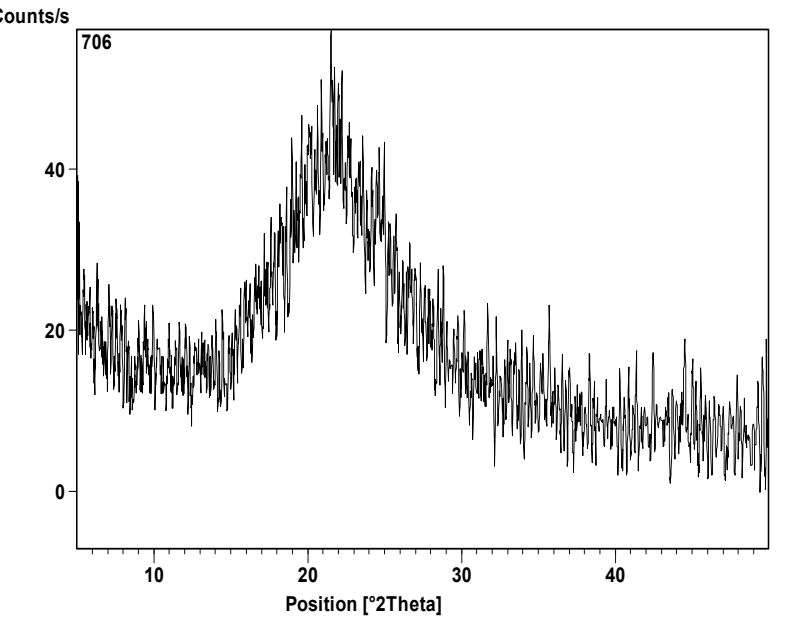

Fig.( 2) : XRD pattern of $\mathrm{RHA}_{2}$
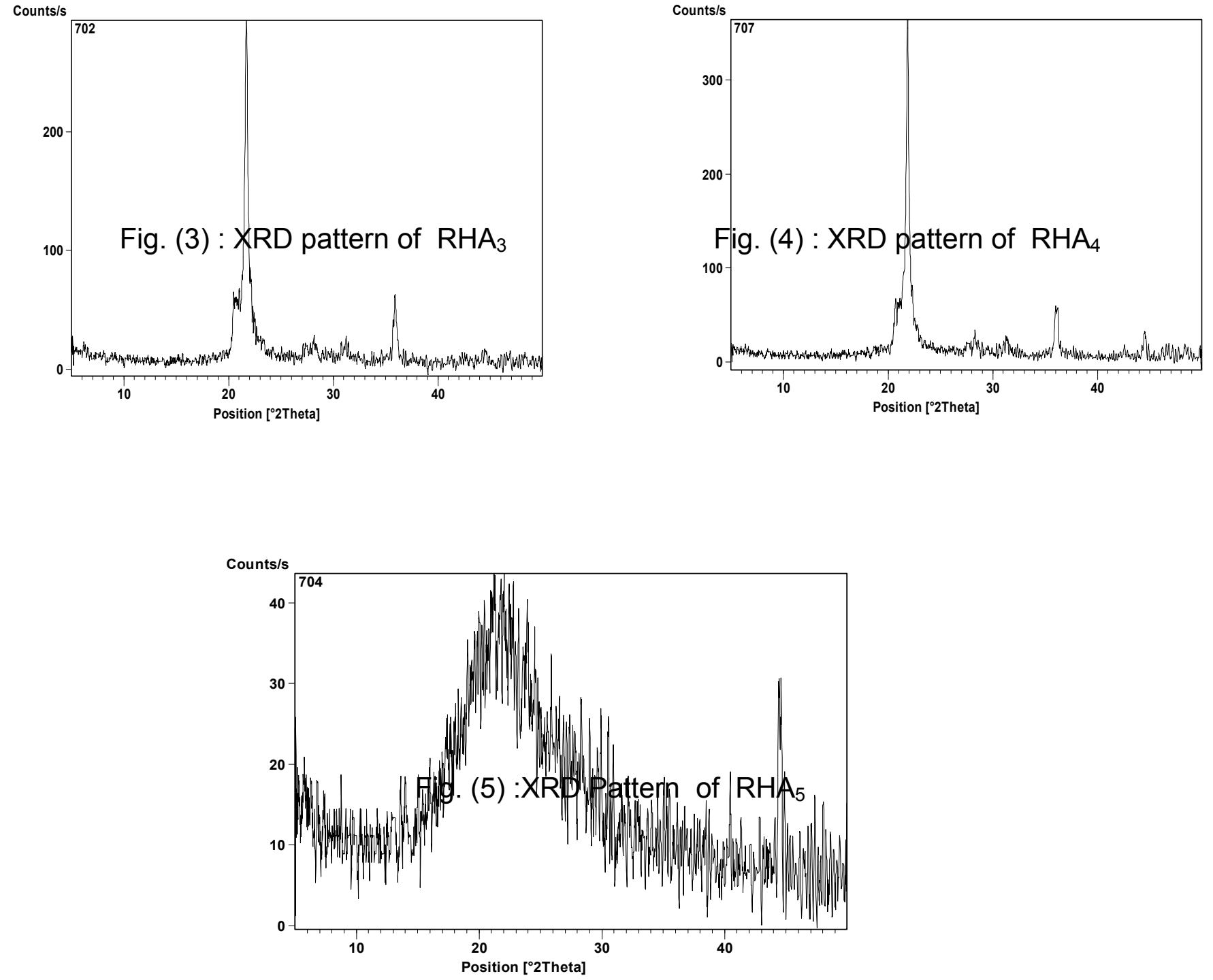


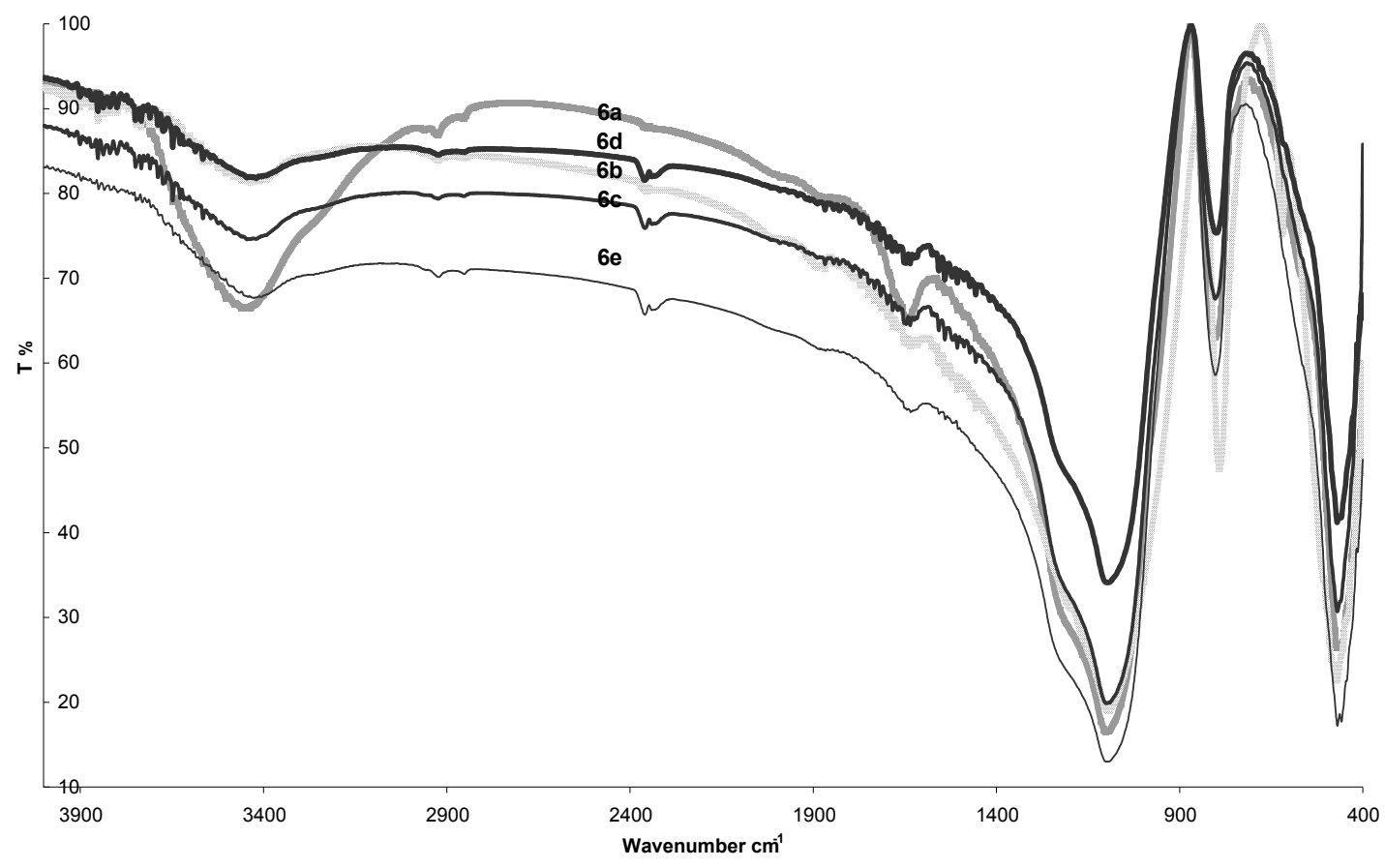

Figs. (6a-e) : FTIR spectrums of a-RHA 1, b. $R H A_{2}, c-R H A_{3}, d-R H A_{4}$ and e- $R H A_{5}$

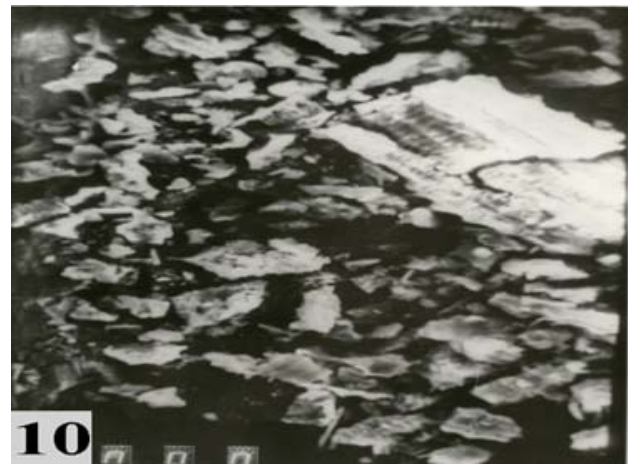

Fig (7) : SEM micrograph of $\mathrm{RHA}_{2}$ (X 200)

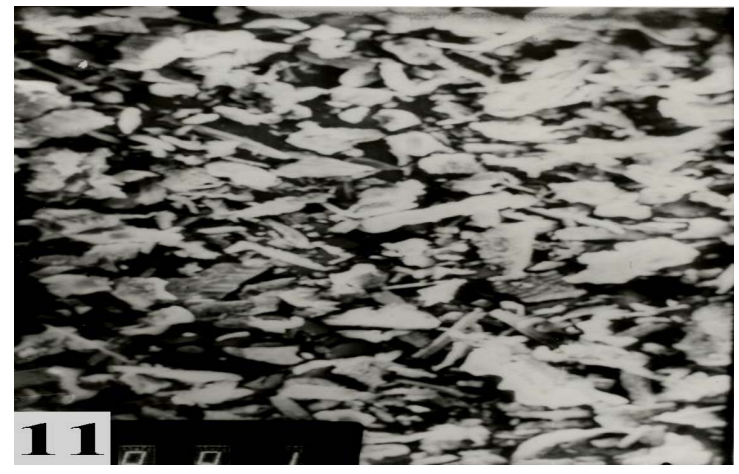

Fig (8) : SEM micrograph of $\mathrm{RHA}_{1}$ (X 200)

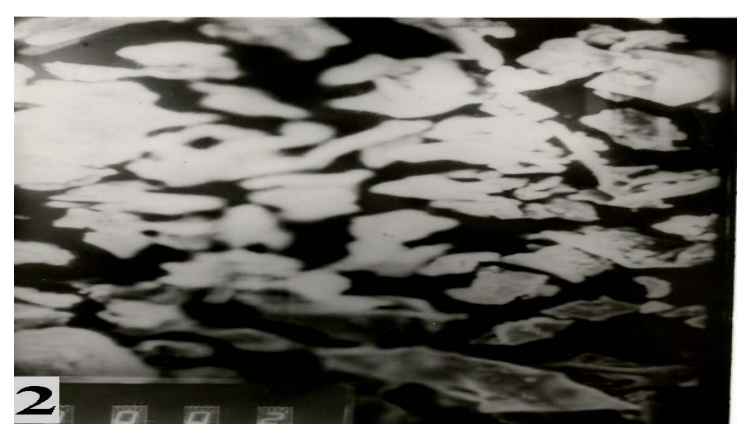

Fig ( 9 ) : SEM micrograph of $\mathrm{SSi}_{5}$ (X 100) 


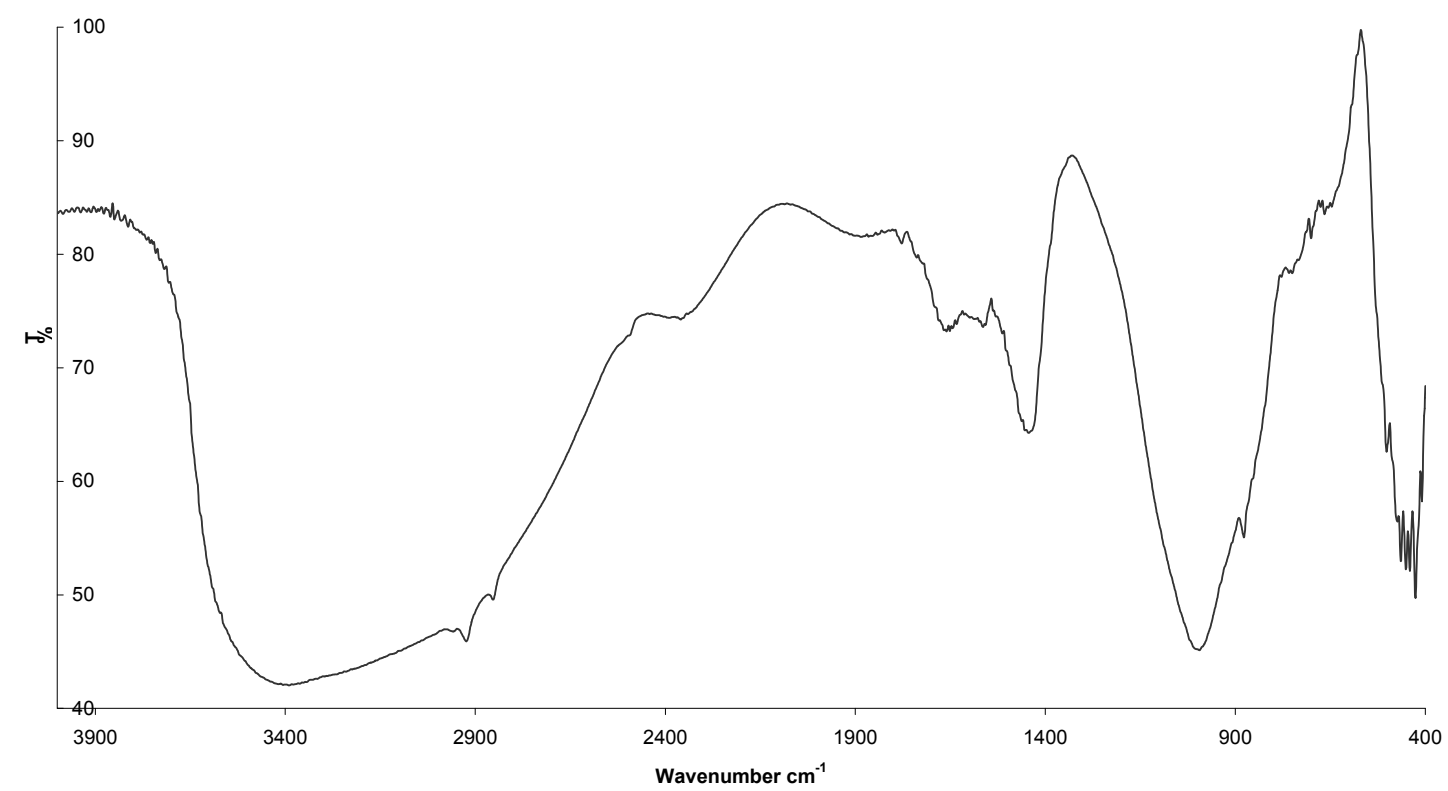

Fig (10) : FTIR spectrum of $\mathrm{SSi}_{5}$

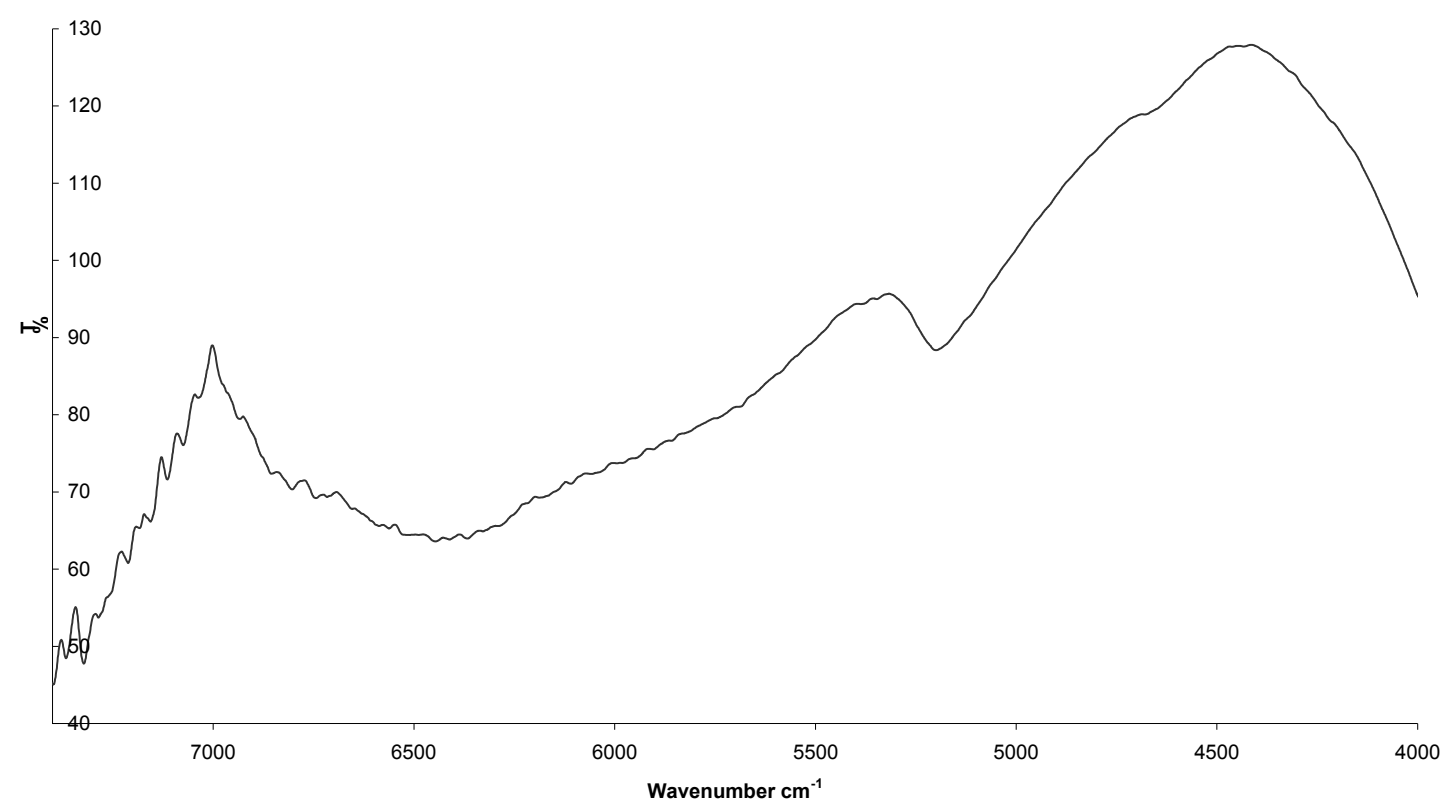

Fig (11): NFTIR spectrum of $\mathrm{SSi}_{5}$ 


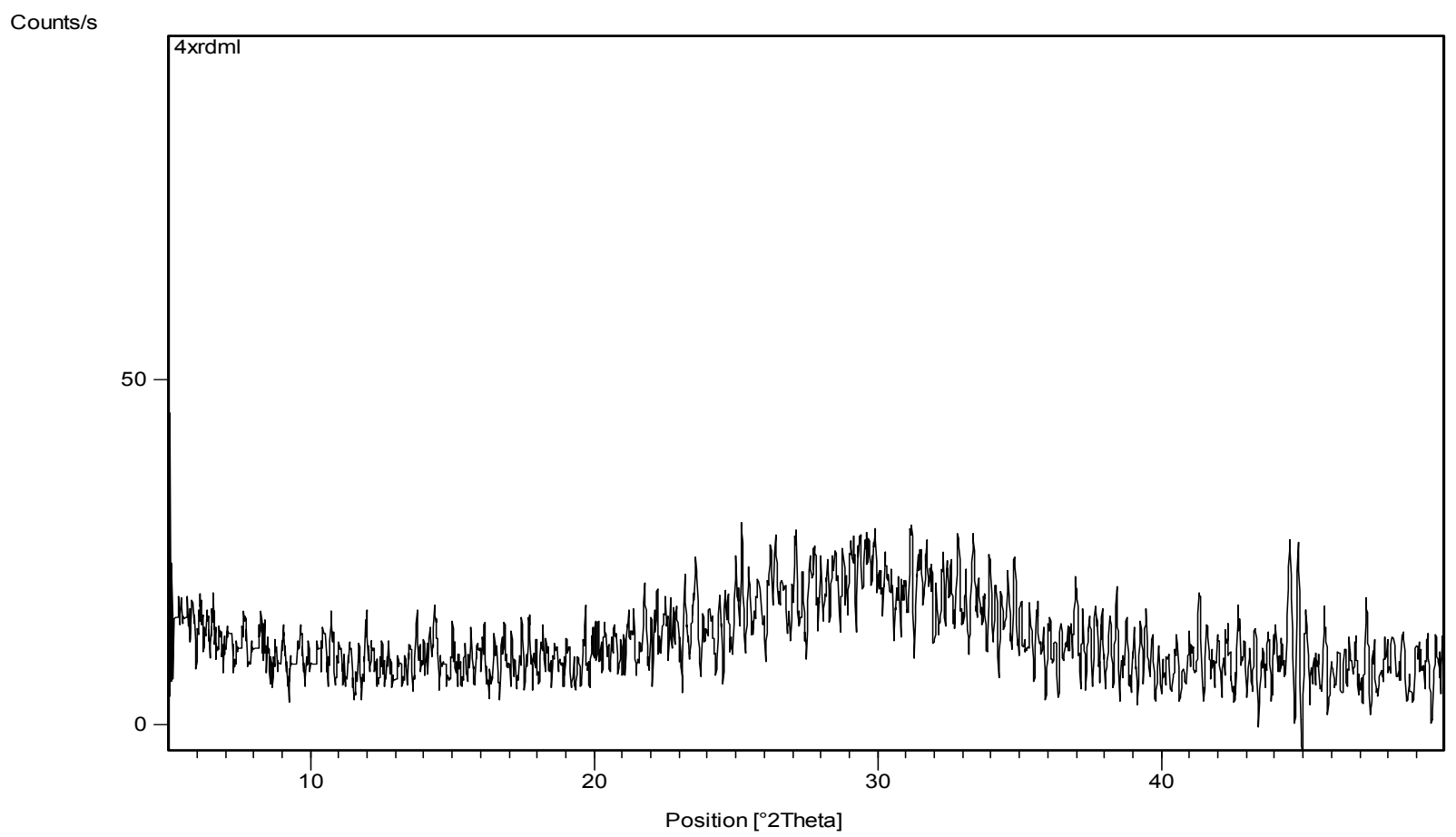

Fig (12) : XRD Pattern of $\mathrm{Ssi}_{5}$

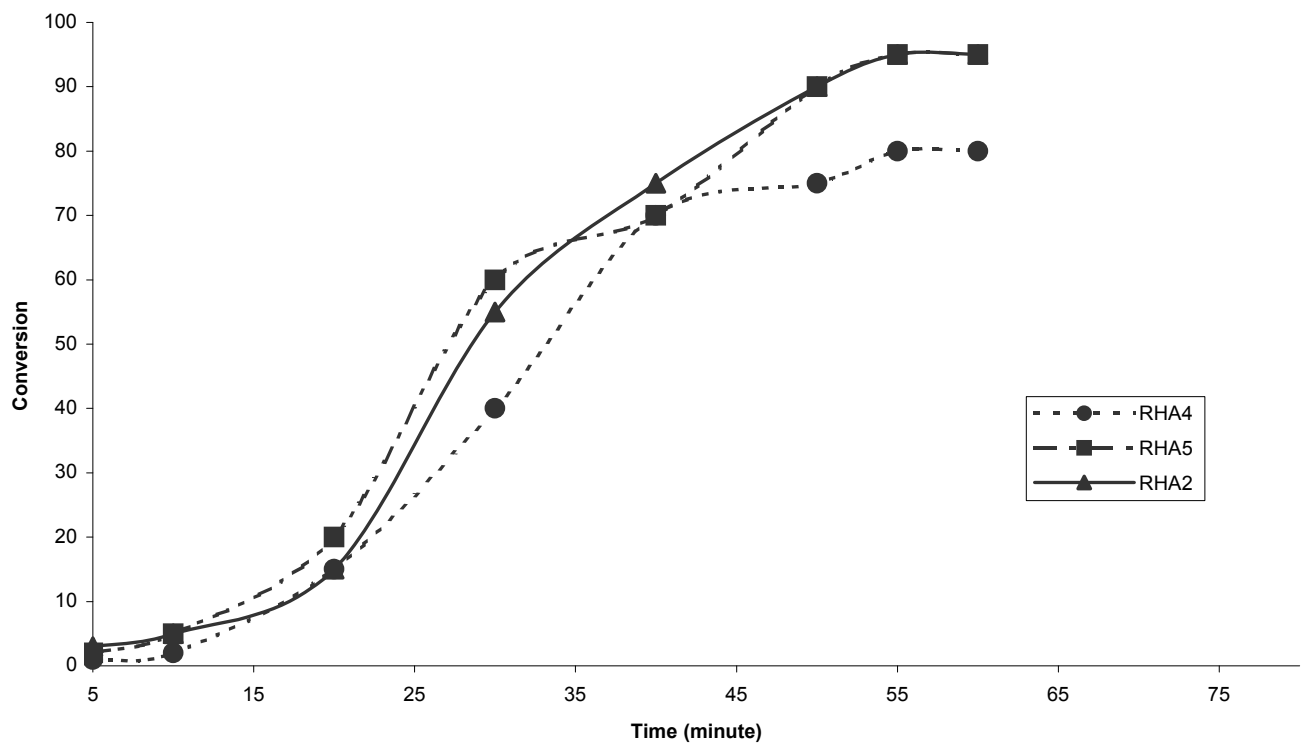

Fig (13) : $\mathrm{RHA}_{2}, \mathrm{RHA}_{4}$ and $\mathrm{RHA}_{5}$ conversion (\%) versus time of neutralization 


\section{REFERENCES}

[1] FAO Statistical Database. (2002). http://apps.fao.org

[2] Beagle, E.C., Rice husk conversion to energy. FAO Agricultural Services Bulletin 37, (1978) FAO, Rome, Italy,

[3] Kalapathy, U., Protor A. and Shultz J., A simple method for production of pure silica from rice hull ash",Bioresource Technology, 73,257-264 (2000)

[4] Riveros, H., and Garza C., "Rice husks as a source of high purity silica", J. Crys. Grow., Vol. 75,126-131(1986),.

[5] Yalcin, N., and Sevic V., "Study on silica obtained from rice husk", Ceramics internationa., 27, 219-224 (2001).

[6] Della V. P., Kuhn I. and Holtza D., "Rice husk ash as an alternate source for active silica production",Materials Letter., 57, 818-821(2002),.

[7] Krishnarao, R. V., Subramanyam, T., and Kumar J., "Studies on the formation of black particles in rice husk silica ash", J. Euro. Cem. Soc., 21, 99-104(2001).

[8] Brinker, C.J. and Scherer, G.W. Applications. In: Sol-Gel Science, The Physics and Chemistry of Sol-Gel Processing. Academic Press, Inc. San Diego, California.. 839-880 (1990).

[9] Iler, R.K., Silica gels and powders. In: R.K. Iler (ed.). The Chemistry of Silica.John Wiley and Sons, New York, New York. 462-599 (1979).

[10] Kamath, S.R. and Proctor, A.,. Silica gel from rice hull ash: Preparation and characterization. Cereal Chem. 75:484-487(1998).

[11] Luan, T.C. and Chou, T.C.. Recovery of silica from the gasification of rice husk/ coal in the presence of a pilot flame in a modified fluidized bed. Ind. Eng. Chem.Res. 29:1922-1927 (1990).

[12] Martin, J. I., The desilification of rice hulls and a study of the products obtained. MS thesis. Lousiana State University (1938)

[13] Lanning, F. C., Silicon in rice. J. Agric. Food. Chem., 11, , 435-437 (1963)

[14] Krishnarao, R. V., Godkhindi, M. M., Chakraborty, M. and Mukunda, P. G., Direct pyrolysis of raw rice husks for maximisation of $\mathrm{SiC}$ whisker formation. J. Am. Ceram. Soc., 74, 2869-2875 (1991).

[15] Krishnarao, R. V., Mahajan, Y. R. and Kumar, T. J., Conver- sion of raw rice husks to SiC by pyrolysis in nitrogen atmosphere. J. Eur. Ceram. Soc., , 18, 147-152 (1998)

[16] Hanna, S. B., Mansour, N. A. L., Taha, A. S. and Abd-allah, H. M. A., Silicon carbide and silicon nitride from rice hulls-III- Formation of Silicon nitride. Br. Ceram. Trans. J., , 84, 18-21 (1985).

[17] Karera, A., Nargis, S., Patel, S. and Patel, M., Silicon based materials from rice husk. J. Sci. Ind. Res., , 45, 441-448 (1986).

[18] Banerjee, H. D., Sen, S. N. and Acharya, H. N., Investigations on the production of Silicon from rice husks by the Magnesium method. Mater. Sci. Eng., , 52, 173 (1982).

[19] Sharma, N. K., Williams, W. S. and Zangvil, A., Formation and structure of silicon carbide whiskers from rice hulls. J. Am.Ceram. Soc., , 67, 715-720 (1984).

[20] Skousen, J., Lilly, R., and Hilton, T., , Special chemicals for treating acid minedrainage, in Skousen, J., and Ziemkiewicz, P.F., eds., Acid Mine Drainage:Control and Treatment: Morgantown, West Virginia, West Virginia University and National Mine Land Reclamation Center, 173-180 (1996). 
[21] Tillman, G.M., , Water Treatment: Troubleshooting and Problem Solving:

[22] Dart, F.J. \& Foley, P.D. Preventing Iron Deposition with Sodium Silicate. Journal AWWA,. 62:10:663 (1970)

[23] Dart, F.J. \& Foley, P.D. Silicate as Fe, Mn Deposition Preventative in Distribution Systems. Journal AWWA64:4:244 (1972).,

[24] Browman, M.G.; Robinson, R.B. \& Reed, G.D. Silica Polymerization and Other Factors in Iron Control by Sodium Silicate and Sodium Hypochlorite Additions. Environmental Science and Technology, 23:5:566, (1989).

[25] Robinson, R.B.; Reed, G.D. \& Frazier, B. Iron and Manganese Sequestration FacilitiesUsing Sodium Silicate. Journal AWWA, 84:2:77 (1992).

[26] Schock, M.R.; Clement, J.A.; Lytle, D.A.; Sandvig, A.M. \& Harmon, S.M. Replacing Polyphosphate with Silicate to Solve Problems with Lead, Copper, and Source Water Iron. Proc.AWWA Water Quality Technology Conference, Paper 5C-2. San Diego, CA (1998).

[27] Rompre, A.; Allard, D.; Niquette, P.; Mercier, C.; Prevost, M. \& Lavoie, J. Implementing The Best Corrosion Control For Your Needs. Proc. AWWA Water Quality Technology Conference,.Paper M14-6. Tampa, FL (1999).

[28] Hadad, A.S. \& Pizzo, P.P. The Effect of Temperature, Humidity, and Silicon Content onthe Oxidation of Fine Iron Particles. Corrosion of Electronic and Magnetic Materials, ASTMSTP 1148. (P. J. Peterson, ed). American Society for Testing and Materials,.Philadelphia, PA (1992).

[29] rice husk market study EXP129,ETSU U/00/00061/REP-DTI/pub URN 03/668, first published (2003).

[30] Andreoli M., G.T. Luca, E.S. Miyamaru Seo Characteristics of rice husks for chlorination reaction (2000)Materials Letters 442000 294-298

[31] Hamdan H. and E. Listiorini, Bul. Kim. 937 (1994).

[32] Hamdan H., Z. Ramli and Y. An Keat, Proc. of the Int.Symp. of Zeolite and Microporous Crystals ZMPC 93,Nagoya, Japan,137 (1993).,

[33] Koon Fung Lam, Ka Yee Ho, King Lun Yeung $\dagger$ and Gordon McKay Selective Ordered Mesoporous Silica Adsorbents Mat. Res. Soc. Symp. Proc. Vol. 788 (2004)

[34] Kloprogge J.T., R.L. FrostRaman and infrared microscopy study of zunyite, a naturalAl13 silicate Spectrochimica Acta Part A 55 1505-1513 (1999).

[35] Theo Kloprogge J.*, Huada Ruan, Ray L. Frost Near-infrared spectroscopic study of $\left[\mathrm{AlO}_{4} \mathrm{Al}_{12}(\mathrm{OH})_{23}(\mathrm{H} 2 \mathrm{O})_{12}\right]^{+7}-\mathrm{O}-\mathrm{Si}(\mathrm{OH})_{3}$ nitrate crystals formed by forced hydrolysis of Al3 in the presence of TEOS Spectrochimica Acta Part A 56 24052411 (2000)

[36] Siriluk C. and S. Yuttapong Structure of Mesoporous MCM-41 Prepared from Rice Husk Ash THE 8TH ASIAN SYMPOSIUM ON VISUALIZATION, CHAINGMAI, THAILAND, 005 23-27 MAY (2005).

[37] Kalapathy U. A. Proctor , J. Shultz "Production and properties of flexible sodium silicate from rice hull ash silica” Bioresource Technology 72, 99-106 (2000). 